\title{
Exploring Contemporary Sea Piracy in Nigeria, the Niger Delta and the Gulf of Guinea
}

\section{Chijioke J Nwalozie ${ }^{1}$ (1)}

Received: 12 February 2020 / Accepted: 9 August 2020 / Published online: 31 August 2020

(C) Springer Science+Business Media, LLC, part of Springer Nature 2020

\begin{abstract}
Piracy is a global crime which impedes the free movement of ships containing people and goods, with its attendant economic ramifications. The perpetrators are usually heavily armed, with sophisticated weapons to enable them to hijack a vessel or vessels and redirect them to their desired location for the payment of an expected ransom.

This paper thematically explores contemporary piracy in the African state of Nigeria, the Niger Delta and the Gulf of Guinea. Nigeria is undeniably a rich country based on its economic, agricultural and population advantages, but criminal activities like piracy have been a significant disadvantage. Most of the piracy activities happening in Nigeria are mainly located in the Niger Delta region, the heart of Nigeria's oil and gas exploration. Some of the unemployed youths of the region use piracy activities as a fightback against the so-called "resource control" embarked upon by the Federal Government of Nigeria, which disadvantages them.
\end{abstract}

Keywords Sea piracy $\cdot$ Nigeria $\cdot$ Niger Delta $\cdot$ Gulf of Guinea $\cdot$ Crime and conflict

\section{Introduction}

This paper aims to explore piracy in Nigeria, the Niger Delta Region, and the Gulf of Guinea. The title is seemingly convoluted, by the mere fact that the Niger Delta belongs to Nigeria; and Nigeria is geographically within the coastal area of the Gulf of Guinea; yet, the title intends to capture vital and specific issues on piracy affecting the area in our contemporary era.

Nigeria is a wealthy nation because of its vast oil resources, some economic diversity, a well-educated population, and an agricultural sector, which provides $35 \%$ of the national gross domestic product [GDP] (African Economic Outlook 2013). Nigeria's GDP grew at an average rate of $7 \%$ per year from 2000 to 2014. From

Chijioke J Nwalozie

chijioke.nwalozie@dmu.ac.uk

1 De Montfort University, Leicester, UK 
2014 to 2016, the oil price had a considerable drop, combined with adverse production shocks; the GDP growth rate plummeted to $2.7 \%$ in 2015 . With the 2016 recession, the economy contracted by $1.6 \%$ (World Bank 2019). Inflation has hovered around $10 \%$ in this decade (Reuters 2013); however, the country experienced high inflation of $11 \%$ in the first half of 2019 (World Bank 2019).

Despite expansion in some sectors like the telecommunication industry, employment creation remains weak and insufficient to absorb the fast-growing labour force, resulting in the high rate of unemployment at $23 \%$ in 2018 , with another $20 \%$ of the labour force underemployed (World Bank 2019). Unfortunately, some of the unemployed youths who are not successful participants in the selective bourgeoisie economy have been politically disruptive, drawing critical economic and military resources away from other areas, including the Niger Delta region where piracy critically thrives.

\section{Contemporary Sea Piracy in the Niger Delta and the Gulf of Guinea}

Modern-day pirates around the world share the legal designation of their historic brethren as "enemies of all mankind" (Kelley 2011: 2286) because they disrupt and hinder the safe navigation of maritime vessels containing goods and people. The Western European incursion into Africa, but Nigeria in particular, seems to have given rise to certain nefarious activities that happen in that part of the world today, and sea piracy is a crucial factor. In 1827 a European naval presence was established at Fernaodo Po. In 1849 John Beecroft was appointed the first British Consul over the Bight of Benin and Biafra, now called Bonny (Jimoh 2015). Before that time, there was no entity called Nigeria. "Piracy," as such, was entirely unknown to the littoral people of the region; albeit the slave trade had existed there for many years (Jimoh 2015). Most of the incidents of piracy then were nothing more than maritime robberies.

In recent times, the sailors were targeted more frequently for robbery onshore, because they were especially vulnerable, displaced, generally uneducated, and usually in possession of cash (United Nations Office on Drugs and Crime [UNODC] n.d). With the rise of containerised shipping, shore leave in Nigerian ports often reduces to a limited number of hours, and consequently, the sailors are highly unlikely to report being victimised. Similarly, vessels at sea are often under tight schedules, and unlikely to delay their voyage to report a local crime, particularly in areas where contact with the police may give rise to further victimisation. Local robbers are aware of this and can attack at any given opportunity when ships are at the port or transferring cargo close to shore (UNODC n.d).

With the end of the slave trade, oil business was in vogue, especially palm oil, and later with the discovery of crude oil in the Niger Delta. Oil theft and bunkering were later associated with piratical activities on the high seas; hence there is a possible link between maritime piracy, oil extraction, the fishing industry, and attractive cargo imported through the territorial waters (Jimoh 2015). The simple logic is that oil sale brings in substantial financial gains. The pirates see it as the major attraction for undertaking the capture and diversion of tanker vessels on the high seas to their preferred destinations, where ransom and or immediate oil sale will give them instant cash.

According to the International Maritime Bureau [IMB] (2019), the seas around the West African subregion are the world's most at risk for piracy (see also Ponniah 2020). Of the 75 seafarers taken hostage onboard or kidnapped for ransom globally, 62 took 
place in the Gulf of Guinea - off the coasts of Nigeria, Guinea, Togo, Benin and Cameroon (IMB 2019). In the first quarter of 2019, the IMB Piracy Reporting Centre (PRC) recorded 78 worldwide incidents of piracy and armed robbery against ships, compared to 107 incidents for the same period of 2018. In total, 57 vessels had successful boarding, which represents $73 \%$ of all attacks. Pirates killed one person, took 38 crew members hostage, and kidnapped a further 37 for ransom (IMB 2019). Drawing from the above report, the best way to qualify the dangerous coastal area of the Gulf of Guinea is to brand it the "centre-point" of contemporary sea piracy (see Ponniah 2020; see also Economist 2019). Figures 1 and 2 buttresse that point as the map further illustrates signs of piracy hotspots. However, Nigeria has the largest share of piratical operations, perhaps due to the oil there. A closer look at Fig. 3 shows that sea piracy across the globe is not as serious as before, thus suggesting that apart from the Gulf of Guinea, piratical activities elsewhere is somewhat under control. How long that will last, remains a question for the future.

Furthermore, piracy attacks in Nigerian waters and the Gulf of Guinea, including those on energy vessels, involve cases of armed robbery at sea, with pirates boarding and robbing the ship while in port or from small speedboats or rubber zodiacs while the vessel is underway (Nincic 2009; ASI Global 2010; Essien 2015). Whereas contemporary maritime piracy occurs in different geographical and environmental locations, some pirates are far more violent and even employ far more sophisticated weapons in their operations than others employ. No matter where they are coming from, pirates seem to have slightly similar modus operandi and egocentric agendas because with the changing dynamics in modern technology, so it is with the changing dynamics in criminal activities such as piracy.

There is an understanding that piracy, like the slave trade, may have largely disappeared in modern times or at least plummeted to levels that would not draw the attention of the international community (Kontorovich 2009). However, this is not the case in the Gulf of Guinea, which is not only one of the world's top oil and gas exploration hotspots, but sadly, a new and dangerous area to shipping, especially around the Nigerian littoral

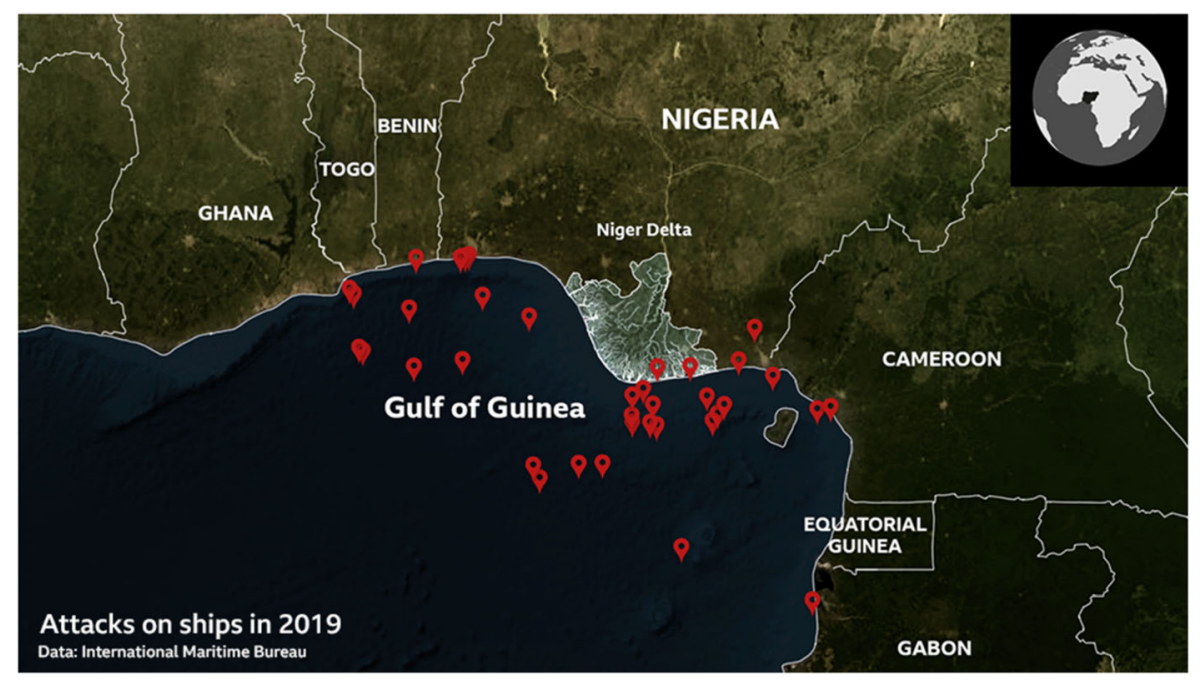

Fig. 1 Attacks on ships in the Gulf of Guinea 2019. Source: IMB (2019) 


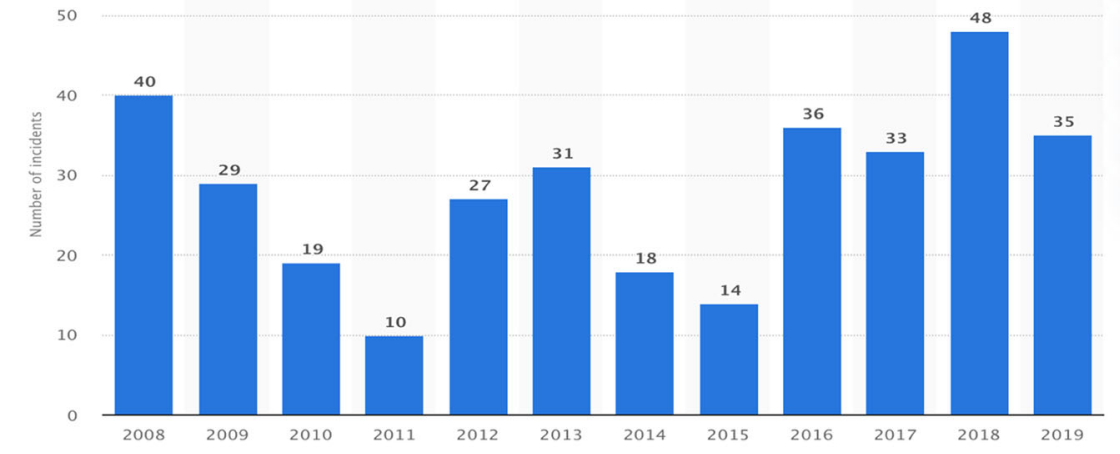

Fig. 2 Actual and or attempted piracy activities in Nigeria 2008-2019. Source: Statista.com (2020)

zone (Amodu 2014). Piratical attacks in the Gulf of Guinea is a severe risk that impedes economic progress in the region, especially Nigeria's shipping industry, thereby deterring prospective investors (Nightingale 2019) the opportunity to do business.

The IMB (2019) report shows that $73 \%$ of all kidnappings at sea and $92 \%$ of hostage-takings took place in the Gulf of Guinea. Moreover, in the first half of 2019, armed pirates in these high-risk regional waters kidnapped 27 crewmembers, and 25 in the same period in 2018. They hijacked two chemical tankers, and a tug involved in another attack. Among the nine vessels fired upon worldwide, eight occurred off the coast of Nigeria, Africa's top oil producer. These attacks occurred on average 65 nautical miles off the coast - meaning they are acts of piracy. These pirates usually arm themselves with weapons such as AK47 rifles and rocketpropelled grenades and therefore pose a significant threat to the crew (ASI Global 2010; see also Economist 2019).

Annual world total (imbcount)

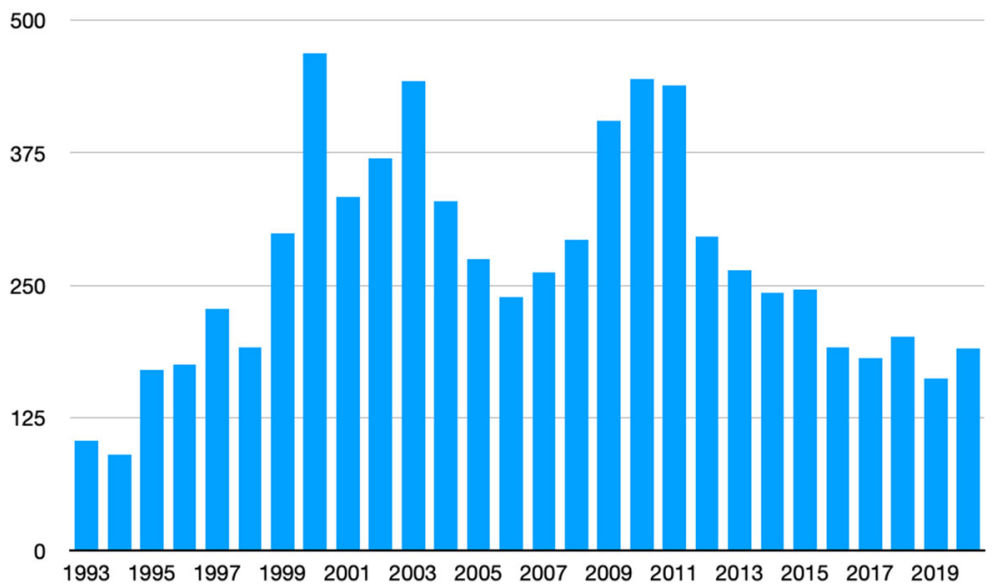

Fig. 3 Annual world total of piracy incidents 1993-2020. Source: IMB Data Centre (2020) 
In 2018, Nigeria witnessed 48 actual and attempted piracy attacks, up from 33 the previous year. In its latest report, the IMB ranked Nigeria again as the highest country for reported incidents, with about 21 attacks out of 77 reported globally (IMB 2019). Data in Fig. 2 spanning between 2008 and 2019 reveal the trajectory of actual and or even attempted piracy activities in Nigeria. The bar chart in Fig. 2 presents an undulating trend in piracy activities. Considering the number of reported incidents, it illustrates that Nigeria is indeed a more piracy prone environment than elsewhere.

In other regions, sea piracy is plummeting. The annual piracy incidents in SouthEast Asia, between 2014 and 2018 was from 141 to 60; and to just three off Somalia, which between 2007 and 2012 was the main face of global piracy (Economist 2019). In 2011, piratical activities created a dangerous zone in the Gulf of Aden, which takes care of one-fifth of global commercial shipping. At the time, the IMB reported 236 attempted attacks in the Gulf of Aden. The Somali pirates were earning an average of almost $\$ 5 \mathrm{~m}$ in ransom per ship, according to a charity - One Earth Future [OEF] (Economist 2019). In the Gulf of Guinea, a former pirate is quoted as saying that: "sometimes we hijack to get money and ransoms. It depends on the ship. We can even get [anything between] 200 million Naira $(\$ 555,000, € 430,330)$ and 900 million Naira" (DW 2015). The issue of piratical earning and spending calls for further research.

As earlier illustrated in Fig. 1, most piracy offences in the Gulf of Guinea occur in the Nigerian coastal environment (see also Economist 2014; Essien 2015), especially around the Niger Delta (Essien 2015; see also Lhuillery 2008). Most pirates are born and raised in Nigeria (Economist 2014). According to Bless Nube, an arrested pirate, "So far we have about 1250 trained pirates across the country. And the truth is, no successful vessel hijack operation takes place in Africa without the knowledge of my gang" (see Usman 2012). As Wolf Kinzel, (frigate captain and expert on maritime security in the Gulf of Guinea region, at the German Institute for International and Security Affairs[SWP]) suggests, since 2018 there have been a quarter fewer attacks on ships. However, there is an increase in hijackings. Also, the pirates have made changes in their operational approach: instead of three seamen, they take the entire crew with them - hostages for ransom (D.W. 2020). Arguably, this display of new criminal tactic is a manifestation of the dynamics of crime and criminal behaviour.

The piracy problem in Nigeria ultimately links to the country's dysfunctional oil industry and the violent politics of the Niger Delta. Given that Nigeria is the world's eighth-largest producer of oil, unfortunately, it suffers from shortages of refined fuels (Economist 2014). Some see this as a problem created by some unpatriotic citizens seeking to stymie national progress and development. According to Dr. Christian Bueger, a Cardiff University researcher in the United Kingdom, one of the significant causes of piracy is corruption, weak law enforcement and poverty (Ben-Ari 2013). These causes suggest that the problem with piracy in Nigeria is traceable to the conspiracy with government officials. Again, as Bless Nube reveals, "we do not work in isolation. We have a network of ministries' workers. What they do is to give us information on the location and content of the vessels to be hijacked. After furnishing us with the information, they would make part payment, and after the hijack, they would pay us the balance" (Usman 2012). Similarly, Perouse de Montclos (2012), claims that some Navy, Customs and Ports Authority staff collude with the pirates by providing insider information, to unleash piracy and armed robbery on vessels navigating the high seas, in the hope to share the proceeds among the parties. 
A 2010 report by the IMB reveals that apart from Somalia, the Gulf of Guinea remains the second most affected region of Africa; and most attacks continue to occur in Nigerian waters.

The year 2009 began with the capture of an oil supply vessel and a subsequent attack on a Royal Dutch Shell tanker. On 20 January 2009, in one of the most worrisome attacks to date, militants from the Niger Delta region attacked the MT Meredith, a tanker carrying 4000 tonnes of diesel fuel. They kidnapped a Romanian crewmember, that was released the next day (Nincic 2009). The militants, believed to be associated with the Movement for the Emancipation of the Niger Delta (MEND), were successful in dynamiting the ship's engine and severely disabling the vessel. While the MEND and other related "copycat" groups had previous histories of attacking and blowing up oil pipelines, this was the first time such an attack had occurred at sea, thus indicating an increasing concern for the future (see Nincic 2009). The number of attacks in Nigeria plummeted in 2009 when compared to attacks in 2008 (when there were 40 reported incidents). Nevertheless, the actual number may be more than twice as high, as many incidents, especially those involving fishing and oil vessels, experience the dark figure of crime (Nincic 2009).

Comparatively, underreporting of piracy incidents is less problematic in South-East Asia and the Gulf of Aden for two reasons. First, there is trust on the part of authorities in South East-Asia regarding their reporting regime. Second, it does not take time to report incidents that occur off Somalia to international navies stationed there since 2009 (Economist 2019). Piracy has been going on for years in the Gulf of Guinea, but nobody fully reports the total number of occurrences by around 50-60\% (D.W. 2020). A significant number of attacks on ships in Nigerian waters (some of which occurred over 31 miles from shore) represent not only a geographical expansion of threats to maritime energy assets, but also perhaps an increasing oceangoing ability on the part of pirates in the area (see Nincic 2009).

As the graph in Fig. 3 suggests, since 1994 when global piracy attacks saw its lowest number of 90 , the year 2019 has had the least attacks and attempted attacks numbering 162 on ships (Prins 2020).

Arguably, the drop in global oil prices would have brought about a decrease in piracy activities in 2020, but the data in Fig. 3 does not seem to suggest such. Oil piracy is not the only thing pirates look for in a vessel. Besides other goods, they hope to take people hostage to attract enormous ransom. However, these statistics require careful consideration for reasons ranging from data collection and collation regimes, and issues of attempted and or actual piracy and or armed robbery activities against ships on the high seas. It should be borne in mind too that the International Maritime Organisation [IMO] tags or labels the reports by member states and or international organisations "acts of piracy and armed robbery 'allegedly' committed..." (see IMO.org database). All these factors must be put into perspective when considering piracy data.

Piracy in Nigeria has become a phenomenon which occurs at any time, and at any given opportunity, which the pirates deem fit. With mobile phone technology, pirates who are mainly male youths can get hold of their required targets. Moreover, from street protests and international lobbying to sabotages and armed struggle, the politicisation of rebel and criminal groups certainly played a vital role in the development of contemporary piracy in Nigeria (Perouse de Montclos 2012). It is interesting to note that all maritime pirates are virtually good or rather skilled swimmers. They are 
likely to come from coastal communities (Perouse de Montclos 2012), which is why piratical activities in Nigeria are dominant in the South and South West of the country.

According to Sky News (2018), pirates kidnapped 12 crew members of Swiss Ship around the Niger Delta littoral communities. Most of the captives were foreign nationals of the Philippines, Slovenia, Ukraine, Romania, Croatia and Bosnia. The capture of a crew gives rise to negotiations for the payment of enormous ransom before an expectant release if the captives are still alive. Some of the prevailing conditions in Nigeria and the Gulf of Guinea are no different from the ones in Somalia when piracy levels increased 10 years ago namely: weak and corrupt governments, political violence, widespread economic hardship and easy access to weapons (see Prins 2020). The current decrease in piracy incidents in Somalia does not mean that their internal problems are over. It does suggest that concerted efforts of international navies with proficiency in tackling sea piracy have made a significant difference. The case of Somalia goes to prove a point that piracy thrives in the littoral countries because of their inability to work cohesively (Economist 2019).

Although no one merely disputes reported cases of piracy activities, nevertheless, it is essential to exercise caution regarding the authenticity of such information. The reason is that different sources might have different information to give, depending on how they collected and collated their data. As the former Managing Director of Nigerian Maritime Administration and Safety Agency (NIMASA), Ziakede Patrick Akpobolokemi, suggests, most of the reported piracy attacks on Nigeria's territorial waters are untrue. They are deliberate sabotage from foreign insurance companies, otherwise called Protection and Indemnity Clubs [PICs] (Rider 2015). However, an undisputable issue remains - sea piracy exists in Nigeria, although it might not be to the degree highlighted by the PICs or it might even be more than that. Nevertheless, piracy issues in Nigeria require urgent attention, especially in the Niger Delta.

Relatively, the volatile pirate attacks along the Gulf of Guinea is seriously taking a toll on Nigerian shipping activities. Worse still, the inability to respond to piracy attacks is resulting in higher insurance premiums and crewing costs for shipowners who encourage them to lobby for stricter security measures (Hassan 2015). For those reasons, the former NIMASA boss has maintained that foreign Insurers are sabotaging Nigeria's economy, especially in the way they report about piracy activities in the subregion (Rider 2015). Beyond insurance rhetoric, maritime piracy in Nigeria has become a "political subject" around those in the corridors of power. Also, it has apparent links to marginalisation, poverty, resource control and the "cancer of corruption" endemic in the whole country (see Okoronkwo et al. 2014). It appears the political will to deal with piracy remains tenuous.

\section{Politics}

People in both public and private life face severe challenges by the effort to live with and overcome discordant tendencies across the country. The federal formation of the country is colonial and remains the present ideological and political solution (Marenin and Reisig 1995). Nigeria has failed to establish "true federalism"; instead, it has fostered the political scramble for power among different ethnic groups. Since Nigerian politics has become a tussle for power between ethnic groups, the issue of policies is 
immaterial in that tussle so much so that the country belongs to the ethnic group or groups that hold power (Anyanwu 1982).

The political events that took place in the old Western Nigeria in 1965 injected into the social structure a new pattern of violence, which became the acceptable avenue to achieve political ends. It started with election malpractices, which the then Federal Government condoned because it belonged to the ruling party at the time - the Nigeria National Democratic Party (NNDP). In the violence that erupted, people were maimed, killed and bodies littered on the streets. This event prepared Nigerians for the civil war that started in 1967 (Rotimi 1984); a war fought for racial or ethnic injustices more than anything else (see Akinwumi 2006). That war is far from being over because there are still social divisions by regions, birthplace and state of origin; ethnic affiliations; religious beliefs; ideological dogmas, and class distinctions (Marenin and Reisig 1995).

Internal conflicts and violence in Nigeria tend to emerge at moments when groups perceive denial of access to what they consider to be their right; be they linguistic, political, economic, administrative, commercial, and religious. The most critical issue, therefore, is the perception and fear of domination by a group (Ibrahim 2000: 41). In recent times, ethnic injustices have continued to occur in different parts of the country. Such may have given rise to the formation of ethnic militias. They include the Oodua Peoples Congress (OPC) in the South-west, Movement for the Actualisation of the Sovereign State of Biafra (MASSOB) in the South-east, Egbesu Boys of Africa (EBA) in the South-south, the Arewa Congress (A.C.) in the North-west, North-central and North-east (Oladele 2007). The mission of these militias has been to seek redress for political and economic disadvantage, the decentralisation of state powers, autonomy and self-determination in the sense of resource control, the provision of security and the right to determine their future in the political landscape of Nigeria (Agbu 2004: 16).

Some other minorities (such as those of the Niger Delta region) have equally formed rebel groups such as Movement for the Survival of Ogoni People - "MOSOP", the Niger Delta People's Volunteer Force "NDPVF", and "MEND". The Niger Delta remains a substantial breeding ground of youth militancy arising from high levels of poverty in the face of considerable investments in oil exploration and exploitation (Mberu 2005: 14). The picture in Fig. 4 shows the Niger Delta militants ready for action on the high sea, while Fig. 5 reveals the Federal Government's preparedness to

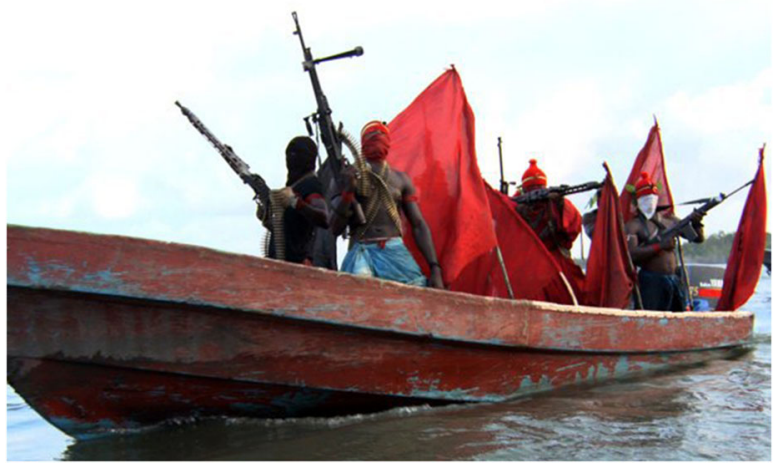

Fig. 4 Niger Delta Militants. Source: Photo via Premium Times, culled from USNI News, 22 June 2015 


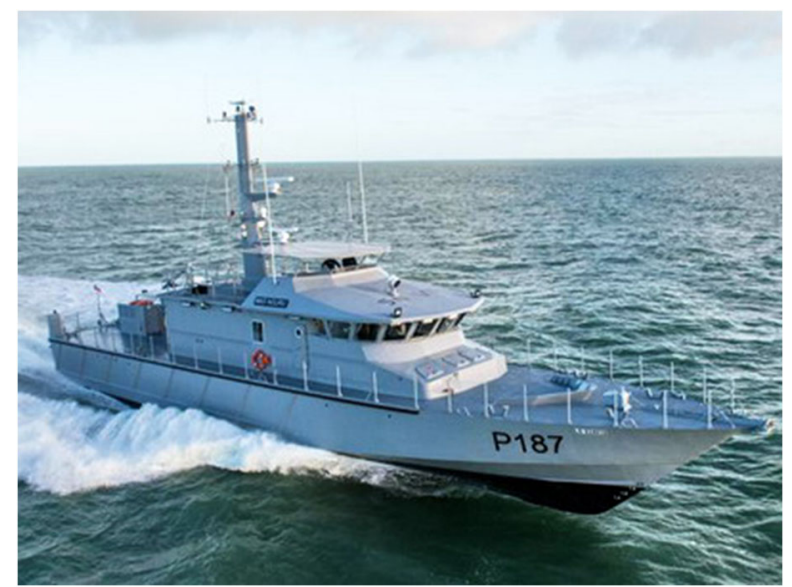

Fig. 5 Nigerian Navy Vessel. Source: culled from DefenceWeb, 2 December 2018

counter sea piracy in Nigeria and the Niger Delta through the provision of speed boats to the Nigerian Navy. There will be more discussion on Fig. 5 later.

The emergence of MEND in 2006 coincided with a sharp increase in piracy activities the following year, thus revealing that MEND is a significant player in maritime piracy in Nigeria (Charlesbois 2012). Both the supporters of MEND and the pirates are natives of tribal communities living in the Niger Delta region (Ikelegbe 2005: 218-219). MEND, is the leading rebel group, which claims to be an "archenemy" of both the Nigerian government as well as the multinational oil companies. MEND faces criticism for having ties to al-Qaeda, but the MEND leaders deny this (Nodland and Odin 2007: 17). Previously, in an early study of piracy, Kania (2009), fell victim to the "ecological fallacy" in indirectly attributing Nigerian piracy to Muslims but this assumption was corrected (see Kania and Nwalozie 2010). Most of the piracies thrive in the Niger Delta - an area of defunct Republic of Biafra - a secessionist region of Nigeria, which fought for independence between 1967 and 1970. The majority of the people there are Christians (see United Nations 2017).

Many other groups are actively participating in the legitimate struggle, as they see it, for better lives. Many attacks have been staged by local villagers and gangs who are annoyed with industry and corrupt government whose primary focus, it appears, has been to "fill their own pockets" (Nodland and Odin 2007). Besides, criminal mobs have exploited the deteriorating security situation purely for financial gain, at times, lending legitimacy from MEND (Nodland and Odin 2007). Over time, it has become necessary to articulate the catastrophic and criminal events in the Niger Delta:

But Nigeria's oil belt, the Niger Delta region is embroiled in resistance against the Nigerian state and the multinational oil companies. The region is generally restive, with pockets of insurrection and armed rebellion. Decades of oil exploitation, environmental degradation and state neglect has created an impoverished, marginalised and exploited citizenry which after more than two decades produced a resistance of which the youth has been a vanguard. A regime of state repression and corporate violence has further generated popular and criminal violence, 
lawlessness, illegal appropriations and insecurity. The Niger Delta is today a region of intense hostilities, violent confrontations and criminal violence. It is pervaded by a proliferation of arms and institutions and agencies of violence ranging from the Nigerian Armed Forces to community, ethnic and youth militias, armed gangs and networks, pirates, cultists and robbers (Ikelegbe 2005: 208).

It is equally challenging to establish what motivates these militant youths in the Niger Delta. Most of them justify their actions in political terms; some of them do so convincingly as they insist on less corruption, cleaner waters and fairer revenue distribution; some do not. As things are, the Nigerian oil crisis has more than its fair share of rouges whose only real motivation is banditry and opportunist crime (Nodland and Odin 2007). Both the Nigerian government and the multinational oil firms feel the pain most. They are left with appalling choices to accept falling revenues and increasing security risks, as their personnel and material assets face threats by an assertive, competent, and highly motivated resistance force (Nodland and Odin 2007).

Since the 1950s, Niger Delta minorities have been agitating against marginalisation, neglect, and the politics of exclusion by the ethnic majority based ruling political parties, and governments of former Eastern and Western regions. This discrimination spiralled into the minority agitation for the creation of distinct regions, which the Willinck's Commission of 1958, disallowed and to a certain extent provided constitutional guarantees in the form of fundamental rights. Nevertheless, the Willinck's Commission granted a special developmental status in the form of a Niger Delta Development Board (NDDB). The materialisation of commercial oil production from the region in 1958 and afterwards raised the stakes high and generated a struggle by the natives for control of the oil resources (Ikelegbe 2005: 214). However, in the 1960s, the new oil economy brought about the political co-operation between the Niger Delta minorities (NDM) and the Hausa/Fulani elite. This alliance came about to foil the aggressiveness and hegemonic intentions of the Yoruba and Igbo neighbours over the NDM. The creation of the Mid-western region and afterwards of states liberated the NDM from the direct political control of the Igbo and Yoruba political elite. After that, the identity struggles of the NDM directs itself towards the oil economy (Ibrahim 2000) and its control.

\section{Economics}

As discussed above, "resource control" or the issue of "patrimony" in the Niger Delta is probably the primary issue at stake that has generated civil unrest. Also, it has taken many lives, destroyed properties and fostered criminal activities such as oil bunkering, kidnapping, armed robbery and piracy on the coast for decades. As the leader of the "NDPVF", Alhaji Mujahid Dokubo-Asari once said, "There is nothing wrong if I take the crude oil found in our land, refine it and sell to our people at NGN 15 per litre. The real 'bunkerers' are the Federal Government, which has been stealing oil from Ijawland since 1958" (The Guardian, 17 October 2004 cited in Ikelegbe 2005: 227).

The Niger Delta region persistently calls for development, but it is disappointing that the Federal Government is not doing much for the benefit of the indigenous people. The radical decision of the local youths has become apparent: "If they do not benefit from the oil output, then they will stop the oil from being produced" (Arnold 2000: 224 
cited in Ikelegbe 2005: 215). Therefore, when the locals see the spread of oil platforms, pumping stations, and other oil installations and infrastructure across the region, they express their displeasure by obstructing the extraction process (Oyefusi 2006). Their overt reactions have taken different patterns over the years. They are the consequences of calculated injustice and neglect of a people whose naturally endowed resources have been the "lifeblood" of the entire nation.

By decrees, oil and gas became owned by the Federal Government, and progressively, the region's entitlements by way of derivation based allocation declined from $50 \%$ to a mere $1.5 \%$ in 1984 and later went up a bit to $3 \%$ in 1999 . Further, the region was marginalised and neglected in the developmental efforts that followed massive oil revenues. The region by the 1990s was one of the least developed and most impoverished. However, and regrettably too, increasing oil exploration had made the region economically and socially drained, courtesy of extensive environmental degradation and ensuing socio-economic disruptions and poverty (Peel 2005: 214).

In the early $1990 \mathrm{~s}$, filled with resentment over their non-participation in the benefits accruing from oil extracted from their land, a majority of Niger Delta youths fearlessly undertook a broad programme to disrupt oil extraction in Ogoniland. Furthermore, in the late 1990s, to disrupt oil flow in Ijawland, Isokoland, and other ethnic groups in the area. The same group of youths were also involved in the abduction of multinational oil companies' staff, and the hijack of their helicopters and boats (Ikelegbe 2005: 215). Those criminal activities were carried out in expectation of some ransom probably paid after severe negotiations between the captors and representatives of the captives. In short, a large pool of restive youths in the region [such as the Ogonis, Ijaws, and Isokos] took advantage of the political alienation on the ground to exploit criminal opportunities available (Ikelegbe 2005). It could be that in their estimation, the risk they took was worth it because it made their voice heard loudly by the Federal Government.

To pacify the people, and for the first time in Nigeria's history, a Federal Minister of Niger Delta region was appointed by then-President Yar'Adua to provide oversight into projects and people's complaints, and above all to be the Federal Government's presence in the region. Successive governments have followed the historic pace set by Yaradua, by the appointment of a Federal Minister of Niger Delta. Furthermore, the Yar'Adua administration, which started in 2007, directed vast sums of money to the Niger Delta region; and multinational oil companies located in the region have begun to pay protection money. Despite that, politicians native to the locality are still in the fight for control of such funds. In tandem, the violent protest has become part of the "political rent-seeking"- how some politicians or an elite group collect money or rather receive bribes directly from multinational oil companies for their selfish ends. Such funds are illegitimate and untaxed. However, their use is to assuage such politicians who may be influential in their local communities. Once the politicians are "settled financially", they can convince the rest of their community to refrain from further insurrection and allow the oil companies to continue their exploration. Overtime grievance has given way to greed (see Watts 2008). Perhaps, it is difficult to assume that the region's "burning issues" are far from over as resource control which is one of the factors responsible for maritime piracy, is still a "grey area" that requires the proper intervention of all the stakeholders.

The Buhari administration wants to further the development of the Niger Delta region. For that reason, the Federal Ministry of Niger Delta had awarded many 
contracts but allegedly to politicians and government officials. In the current political climate, the Federal House of Representatives (FHR) is investigating the Federal Ministry of Niger Delta over a corruption scandal about the award of many Niger Delta Development Commission (NDDC) contracts. At the time of completing this paper, the probe by the FHR was at its earliest stages. Media reports reveal that those alleged to have benefitted from the fraud include some top government officials, the ruling All Progressive Congress (APC) Party officials and former governors. Others include some members of the National Assembly, a judge, senior police and army officers, some traditional rulers, and the Economic and Financial Crime Commission [EFCC] officials (Saharareporters 2020; Odunsi 2020).

Furthermore, recriminations and counter recriminations are on the horizon. A dramatic episode captured by both the national media outfits, and the social media, was the sudden fainting of Acting Managing Director in the NDDC while answering questions from members of the FHR Committee on NDDC. If members of the FHR do not take the fraud investigation seriously, and the perpetrators able to face justice, it might exacerbate youth restiveness, piracy and allied crimes in the Niger Delta. The reason being that those who should ab initio benefit from the outcomes of the contracts (Niger Delta communities) are still suffering from untold hardships created by the bourgeoisie. When the corruption scandal probe ends, a new Bill should urgently be passed by the National Assembly and assented by the President of the Federal Republic of Nigeria, ensuring that politicians and public servants do not apply or tender for government contracts in the country.

In an attempt to fight maritime piracy, the government, in August 2014, appointed a one-time Delta warlord from Bayelsa State, General Boyloaf, as leader of a maritime security outfit in his home state of Bayelsa. It is worth remembering that Boyloaf once led an aggressive attack on a Shell oil platform $120 \mathrm{~km}$ (74 miles) offshore. According to Boyloaf, "the government was having serious security challenges in the creeks. They chose me to deal with it as the creeks are my terrain. I was born in the creeks, I fought against the government in the creeks, and I will now use that knowledge to hunt the pirates" (see Harper 2014).

With the Buhari administration in office, the military have taken over the safeguarding of national pipelines with security reassurance. Earlier President Buhari had ordered the cleaning up of oil spillage in the Niger Delta. This situation had adversely affected the overall well-being of the locality, marine life, maritime transportation, and indeed the economic growth of the entire country.

Maritime transportation is a very crucial economic sector that under-props not only international trade but also enhances global economic integration and globalisation (Igbokwe 2015). The reason is that $80 \%$ of global trade moves via marine vessels (Essien 2015; Gosalbo-Bone and Boelaert 2015). This marine transportation represents around 93,000 merchant vessels, 1.25 million seafarers and almost six billion tonnes of cargo annually (Essien 2015). Besides, Nigeria being a coastal and an import-oriented state depends mostly on international shipping for revenue from the mining of natural resources, primarily crude oil, and of course, not excluding the movement of essential goods to and from other countries (Igbokwe 2015). That is to say; maritime transport is necessary for the stability of Nigeria's economy.

Moreover, the Gulf of Guinea remains a critical maritime route for international shipping from Europe to America, to West, Central and Southern Africa. The region's 
importance in the global energy supply is evident due to its proximity to Europe and North America for the transportation of crude oil and gas from the region (Igbokwe 2015). At least $20 \%$ of Europe's oil and gas comes from the Gulf of Guinea (D.W 2020). Therefore, the Gulf of Guinea is considered a strategic location due to its natural resources.

Besides, piracy has had negative impacts on global trade and the growth of the global economy (Igbokwe 2015). Contemporary maritime piracy has become a pressing issue which costs the global economy \$24.5 billion in a year (Knorr 2015). On the domestic arena, piratical activities on the Nigerian waters have resulted in economic sabotage that is already affecting the country's image at the international scene and impeding national development (Hassan 2015). Estimate revels that Nigeria loses 150,000 barrels of crude oil every day to oil thieves, which amounts to about N2.5 billion daily, and over N900 billion annually (Amodu 2014), thus alluding to a corrupt society and a corrupt economy. Although this data may not represent the full scale of the losses, depending on where and how information is coming from; at least it tries to cast a shadow on the severe economic problem facing Nigeria, which partly arises from piracy.

Also, the coronavirus disease "covid19" pandemic has adversely affected individuals, countries and indeed the global economy. Shipping of goods is affected, and global piracy activities are gradually picking up beyond last year's figures (see Prins 2020). Now, the rate of covid19 infection in Nigeria is minimal compared to Western societies, India and some Latin American countries like Brazil. With the struggling nature of policing piracy activities in the Gulf of Guinea and elsewhere, if there is a more significant increase in the rate of covid19 infections and deaths, governments' attention may withdraw entirely from piracy issues to focus on Covid19. When that happens, opportunist pirates might cash in on that to hijack the vulnerable vessels that fall prey to them (see Prins 2020). Since what affects Nigeria affects the Gulf of Guinea; governments in the region, and especially Nigeria must be up to speed in ensuring against the threat to economic activities as a result of maritime piracy, hence the need for high-level security operatives that patrol the waters.

\section{Projection of Naval Power}

The fight against piracy is a high-security challenge for the Nigerian Navy. Besides the joint global efforts to tackle piracy through maritime patrol, the Nigerian Navy had in January 2015 installed at least, eight automated camera-equipped surveillance towers in the littoral zone just off the Nigerian coast (Oseghale 2015). Before that, on 1 August 2006, the Federal Government established the NIMASA by merging the National Maritime Authority (NMA) with the Joint Maritime Labour Industrial Council (JMLIC), both former parastatals of the Federal Ministry of Transport (Amodu 2014). As the former Director-General of NIMASA, Mr. Ziakede Akpobolokemi had said: since its establishment, NIMASA has strived to live up to its 'Mission Statement': "to achieve safe, secure shipping, cleaner oceans and enhance maritime capacity in line with best global practices towards Nigeria's economic development" (Amodu 2014).

Akpobolokemi's management of the Agency recorded quite some successes in the fight against oil thieves and other criminals on Nigerian waters by arresting, seizing and 
detaining many found to have breached any of the provisions of the NIMASA, Cabotage and the Merchant Shipping Acts (Amodu 2014). These successes have been possible because the Agency's team have been working with the Nigerian Navy and the Nigerian Air Force, which used sea and air patrols surveillance, respectively. They quickly put up a response and reception plan, which led to the hijackers abandoning their mission and fleeing (Amodu 2014). According to Akpobolokemi, the new 24hour Surveillance Centre is capable of detecting boats, ships, and objects of predefined cross-section floating on water, which includes any aircraft that ditches and remains on the surface during satellite over-flight. Its abilities further include, but not limited to setting range rings and restricted areas for which when penetrated by an intruder, the system gives an alarm thereby alerting the operator and watch-keeper (Amodu 2014). This signal will then make it clear to security operatives to react to a possible attack on a maritime vessel offshore.

The former NIMASA boss argues that bringing an end to piracy, armed robbery and kidnapping on the nation's territorial waterways is a non-negotiable venture. The Agency have taken proactive initiatives ahead of pirates within the areas and with a promise to continue to frustrate kidnappers in their evil acts (Hassan 2015). Similarly, the former Flag Officer Commanding (FOC) Eastern Naval Command, Rear Admiral Charles Obiora-Medani, stressed that the rate of criminal activities perpetrated by sea pirates along the waterways in Cross River and Akwa Ibom States had reduced drastically. The former FOC pointed out that the drastic drop in oil theft and other criminal acts within the waterways is consequent upon the regular and active naval patrol along the Calabar-Oron and Ikang waterways. Such action has made it difficult for sea robbers to attack oil service vessels and international boats that apply between Nigeria, Sao Tome, Cameroun and Gabon. However, pirates have now changed course to attacking soft targets which are passenger boats (Hassan 2015). Arguably, if a new procedure is put in place to control or deter criminals, they (criminals) will, in turn, redesign their escape routes to perpetuate their criminal operations. To further help combat piracy on the Nigerian waters, the Federal Government bought four patrol ships - NNS Centenary, NNS Prosperity, NNS Okpabana and NNS Sagbama, and handed over to the Nigerian Navy for use in their operations. Despite the launched ships, the criminal activities of pirates are still thriving along the Nigerian coasts (Hassan 2015).

Back in the old days, in 1956, a small Nigerian Naval Force was established with ten small vessels, adequate only for coastal security functions. It acquired a corvette in 1964, and two more were added in 1973. The Soviet Union supplied several motor patrol boats in the late 1960s, providing Nigeria with the necessary resources to combat any pirate crew in her territorial waters (Nigerian Navy 2007). However, much of the Nigerian Navy still consists of older ships; some transferred to Nigeria from Great Britain upon her independence in 1960. Many of these were World War II surplus. Maintaining such an ageing fleet has been a significant burden on Nigerian Navy resources (Nigerian Navy 2007).

Recently, in 2018, the Nigerian Navy acquired 16 vessels (10 small boats and 6 patrol vessels) to help protect the maritime environment, including the oil and gas infrastructure (DefenceWeb 2018). Probably, this project aims at having up to date state of the art equipment that can weaken and surmount the nefarious activities of sea pirates, which affect both national and global economies. Figure 5 above shows one of the new patrol boats (P187) with the name: Nigerian Navy Ship "NNS Nguru", after its 
commissioning. It is a 35-metre vessel designed to be equipped with two $12.7 \mathrm{~mm}$ and one $20 \mathrm{~mm}$ cannon (DefenceWeb, 2018) to prevent and fight piracy and allied criminal activities on the littoral space of Nigeria.

Although all of the West African states are trying to strengthen their coast guards with Western help, and there are ongoing efforts to share information on shipping and attacks; however, if there is to be a lasting solution to piracy, Nigeria will have to take the lead in regularly patrolling its waters and restraining illegal activity (The Economist 2014) because according to an arrested piracy suspect, Bless Nube:

The code name for piracy is 'COJA', and it is very lucrative just as it is dangerous because one may be confronted by security agents in the process, or even get arrested as I am now. But it will be difficult for the President to win the war. If he must win, then he has to look inward. Lagos State, for instance, is a major coastal place where we meet to discuss on our next target. So, government must first search its big men if it is serious in winning the war (Usman 2012).

The above quotation implies that some unpatriotic political office holders in Nigeria are complicit in piracy activities. It is utterly disappointing that government officials who should be role models to youths end up conniving with them in crime, thereby scandalising them and approving criminal behaviour as the objective norm. When things like that happen, it becomes challenging to combat sea piracy.

At times, pirates can defeat the Navy in the gun battle. For example, armed pirates raided the oil dredger MV Ambika as it worked in the dangerous waterways of the Niger Delta late on Thursday 2 January 2020. During the incident, a team of naval rescue squad came on a rescue mission, but during the gun battle, the pirates succeeded in killing four of the naval personnel of the squad. Before the arrival of the naval rescue team, the pirates had gained access into the vessel and abducted two Russians and one Indian who were part of the eight crew members onboard the vessel (Agence France-Presse 2020). An occasion of this nature raises questions about what went wrong on the Navy's side regarding professionalism and the use of resources. Also, it calls for a thorough investigation regarding what made pirates win the battle, in the hope that it does not happen again.

On 24 June 2019, President Muhammadu Buhari signed into law a Bill of the National Assembly, now called the "Suppression of Piracy and Other Maritime Offences (SPOMO) Act 2019". The SPOMO Act recognises the relevance of the United Nations Convention on the Law of the Sea [UNCLOS] 1982, and the Unlawful Acts against the Safety of Maritime Navigation [SUA] 1988 and its Protocols. Interestingly, there is a replication of the UNCLOS definition of piracy in the SPOMO Act 2019. The Act appears to be the first of its kind in West and Central Africa, with some clarity in the fight against piracy offences (Foyeku 2020). However, the SPOMO Act 2019 is a "stand-alone" but falls short of linking piracy in tandem with other transnational organised crimes (Ogbonnaya 2020). That gap in the law might allow pirates to abuse the system by committing other crimes alongside piracy which the Act does not cover. That aside, the SPOMO Act 2019 is a milestone in Nigeria's lofty ambition to tackle maritime piracy. It is also a wake-up call for other countries within the Gulf of Guinea to enact similar domestic laws, and then aim at partnering at the regional 
level in creating a transnational legal instrument that will stem the activities of sea pirates in the region.

There is no doubt that a closer and regular co-operation among Navies within the region will drastically reduce the menace of the pirates. In 2016, the West African Navies did a coordinated job to recapture the hijacked M/T Maximus successfully, but much of that co-operation was ad hoc. There was no formal mechanism in place at the time, but the Navies did what they did as a result of relationships as neighbouring countries (Ralby 2020).

Most recently, the Nigerian Navy rescued both the hostages and the Chinese fishing trawler Hailufeng 11, licensed to fish in Côte d'Ivoire, and safely escorted them to Lagos. The vessel was hijacked by pirates on Thursday, 14 May 2020 in the Ivorian exclusive economic zone with 18 crewmembers aboard - eight Chinese, seven Ghanaian and three Ivorian nationals. The tracking of the vessel became possible through a coordinated effort of several African States and Organisations such as NIMASA. However, the Nigerian Navy was able to interdict the Chinese fishing vessel 140 nautical miles south of the Lagos Fairway Buoy at about 22:10 hours local time on the night of 16 May 2020. When accosted, the pirates were hesitant to stop, but the Nigerian Navy's Special Boat Service embarked on the NNS Nguru, carried out an opposed boarding while underway at 9 knots (Ralby 2020). Very soon, the arrested pirates will be the first to be prosecuted under the new SPOMO Act 2019 (Babalola 2020). The outcome of the trial will go a long way to sending a clear message to sea pirates that their criminal activities on the Nigerian littoral area will no longer be business as usual. Already the Nigerian Navy had warned piracy perpetrators to desist from criminal activities within the Gulf of Guinea coastline (Babalola 2020). Now, with the support of the new legislation, pirates can be arrested by the Navy and then arraigned in court for prosecution. The security operatives and indeed, the criminal justice agencies owe Nigerians the patriotic duty to ensure that corruption does not stand in the way of justice for the country, the victims and even the pirates themselves.

Nonetheless, the novel collaboration of the Nigerian Navy and NIMASA has indeed paid off. Now there is intelligence sharing between NIMASA's Command, Control, Communication, Computers, and Intelligence Centre [C4i] of the Deep Blue Project, which had been in operation every day since last year. Also, there is the Navy's "Falcon Eye" that tracks pirates in operation (Foyeku 2020). Recently, the IMO SecretaryGeneral, Kitack Lim praised the new Director-General of NIMASA Bashir Jamoh, for his bold and dynamic approach to maritime security (Global 2020). Jamoh's determination to achieve a robust maritime industry for Nigeria anchors on three main areas, namely, maritime security, safety, and shipping development (Abiodun 2020). With these new initiatives, piratical activities are easily detectable, and the perpetrators can be arrested and prosecuted. All the control and preventive measures against piracy have become necessary due to the nature of contemporary piracy so that Nigeria and indeed, the Gulf of Guinea will become safe for maritime transportation.

\section{Conclusion}

Piracy in the Gulf of Guinea, and in particular Nigeria has had a protracted history. It is traceable down to the trans-Atlantic slave trade era, even though the slave trade 
predates it. In the past few years, piracy seems to have had an impressive decline in some parts of the world. However, it appears to have hiked in the Gulf of Guinea, and with particular reference to Nigeria, which is concerning to the maritime environment and world community. As noted before, the scale of the problem appears to have suffered colossal neglect; hence not many Nigerians seem to be aware of it. The figures may vary regarding the magnitude of attacks, depending on the data source, which explains why foreign insurers should be circumspect about labelling Nigeria as a critical piracy area that is very risky for the navigation of maritime vessels.

In attempting to solve the problem of piracy in Nigeria, it is primordial to address the cancer of corruption, poverty, and youth unemployment. The Federal Government and the National Assembly have a crucial role to play here by being transparent and accountable to the Nigerian public. The current and yet unfolding NDDC contracts' fraud indicting Federal Government Officials and some members of the National Assembly is not only scandalous; however, it undermines all the Federal Government's developmental initiatives in the Niger Delta region. To avoid future corruption scandals like this, the National Assembly should urgently enact new legislation that prohibits politicians and public servants from directly or indirectly tendering for government contracts. Most importantly, social amenities and job creation should be a priority for the government in combating piracy.

Piracy in the Nigerian waters both increases and decreases, yet available data reveal that it remains a severe problem in Nigeria. Most of that piracy have links to oil extraction in the Niger Delta region; hence pirates sailing from local riverine communities seize oil tankers and hold them in hope for ransom. Their claim on the abundant mineral resources of their region finds some basis upon complaints that the Federal Government is taking the wealth of the area and not sharing it equitably with the local population. A "pop-Marxist" ideology has developed among these communities, and their actions aim at redressing this perceived inequity.

The Nigerian Navy have shown their military prowess in fighting piracy within the Niger Delta and indeed the Gulf of Guinea. With a few examples mentioned above, they have successfully foiled piracy activities, arrested the culprits and released the hostages. Effective combating of the criminal operations of pirates requires the ongoing teamwork with NIMASA and committed regional security apparatuses so that the Gulf of Guinea can become less dangerous for navigation of vessels carrying goods and people. There are few occasions when pirates overpower the Navy, leading to fatalities. Such occasions should call for thorough investigation so that they do not reoccur.

Nigerian piracy is related to control over the abundant oil resources of the country. While Nigeria is rich in resources, economically, much of it suffers from poverty and backwardness. Its oil and mineral resources are not its own, but the multinational corporations are controlling them. Its political institutions were modelled on those of the British colonial authorities but have evolved after the civil war and internal ethnic strife. Governmental corruption is notorious so that the poor receive little from the wealth that surrounds them. Its pirates are focused on attacking the ships serving the corporations exploiting her natural wealth (Lhuillery 2008).

The Nigerian pirates and Delta region insurgents do not originate from the Islamic factions of the country, and indeed many - if not most - pirates are not Muslims. They all are products of a radicalised Nigerian political environment in which MEND and other groups find support and comfort from some radical Jihadists (Nodland and Odin 
2007: 17) as well as other factions. Nevertheless, MEND concepts seem to be "folkMarxist", and they are not a Jihadist-clone organisation. Instead of radical Islam, most Nigerian pirates find a rationalisation for their activities in the form of popular Marxism and a desire for ethnic or tribal independence. They see themselves as exploited by the multinational oil companies, such as Royal Dutch Shell. Again, they feel that they are not receiving a fair share of the enormous oil wealth being taken from under their lands by the Federal Government and the expatriate multinational corporations.

As noted earlier, Nigerian piracy is most prevalent in the waters of the Niger Delta and the adjacent Atlantic Ocean. Facing massive economic losses from piracy, the Federal Government have stepped up their anti-piracy activities (Akinsanmi 2008). One dramatic step is again, the enactment of the SPOMO Act 2019, which the judiciary will seek recourse to, for the first to prosecute the immediate arrestees. The outcome of the prosecution will hopefully, generally, deter future pirates from attempting to operate on the Nigerian waters. Nevertheless, combating contemporary piracy is a national and transnational project for all the stakeholders to work in unison, to ensure the safe navigation of vessels carrying people and goods within the Nigerian littoral environment and the Gulf of Guinea. To do so, it will help boost economic development in the region.

\section{References}

Abiodun, E (2020) Nigeria: winning war against pirates. https://allafrica.com/stories/202006190054.html. Retrieved 4 August 2020

African Economic Outlook (2013) "Nigeria 2012," African economic outlook, pg. 4. http://www. africaneconomicoutlook.org/fileadmin/uploads/aeo/PDF/Nigeria\%20Full\%20PDF\%20Country\%20Note. pdf. (Retrieved 7 April 2013)

Agbu O (2004) Ethnic militias and the threat to democracy in post-transition Nigeria. Nordiska Afrikainstitutet, Sweden

Agence France-Presse (2020) 'Pirates' kill 4 Nigerian navy personnel, kidnap 3 foreigners. https://www. courthousenews.com/pirates-kill-4-nigerian-navy-personnel-kidnap-3-foreigners/. Retrieved 31 July 2020

Akinsanmi, G (2008) "Nigeria: national loses N25bn to piracy, sea robberies," https://www.AllAfrica.com, 6 December 2008. http://allafrica.com/stories/printable/200812060006.html. Retrieved 6 May 2009

Akinwumi O (2006) Youth participation in violence in Nigeria since the 1980s. In: Daiute C, Beykont Z, Higson-Smith C, Nucci L (eds) International perspectives on youth conflict and development. Oxford University Press, New York

Amodu, B. (2014) High piracy incidence: threat to Nigeria's economy, Newswatch times. http://www. mynewswatchtimesng.com/high-piracy-incidencethreat-nigerias-economy/. Accessed 14 Sept 2015

Anyanwu JC (1982) The bases of political instability in Nigeria. J Black Stud 13:101-117

ASI Global (2010) Maritime response. ASI Global Response.com. http://www.asiglobalresponse. com/downloads/piracy_report.pdf

Babalola, Y (2020) Anti-piracy: as NIMASA triumphs against 10 pirates. https://leadership.ng/2020/05/22 /anti-piracy-as-nimasa-triumphs-against-10-pirates/. Retrieved 28 July 2020

Ben-Ari, N (2013) Piracy in West Africa: a bumpy road to maritime security. http://www.un. org/africarenewal/magazine/december-2013/piracy-west-africa. Retrieved 25 September 2015

Charlesbois J (2012) Pirate economics: the economic causes and consequences of contemporary maritime piracy in sub-Saharan Africa. A thesis submitted in partial fulfilment of the requirements for the degree of master of development economics. Dalhousie University Halifax, Nova Scotia August 2012

D. W 2015 Nigerian piracy on the rise in the Gulf of Guinea. https:/www.dw.com/en/nigeria-piracy-on-therise-in-the-gulf-of-guinea/a-43375090. Retrieved 6 August 2020

D.W (2020) Who will help solve Africa's piracy problem in the Gulf of Guinea? https://www.dw. com/en/who-will-help-solve-africas-piracy-problem-in-the-gulf-of-guinea/a-52367209. Retrieved 31 July 2020 
DefenceWeb (2018) Navy commissions new vessels. http://wwwdefencewebcoza/indexphp?option=com content $\&$ view=article \&id=53011:nigerian-navy-commissions-new-vessels \&catid=51:Sea \&Itemid=106. Retrieved 2 December 2018

Economist (2014) Piracy in Africa: the ungoverned seas. The Economist. www.economist.com. Retrieved 25 October 2015

Economist (2019) Crime wave: the Gulf of Guinea is now the World's Worst Piracy Hotspot. https:/www. economist.com/international/2019/06/29/the-gulf-of-guinea-is-now-the-worlds-worst-piracy-hotspot. Retrieved, 4 August 2020

Essien, B. S (2015) Sea piracy and security challenges of maritime business operation in Bayelsa State, Nigeria: an empirical study. Int J Humanit Soc Sci 5-2:213-221

Foyeku, S (2020) IMO commends NIMASA, navy on fight against piracy. https://www.shipsandports.com. ng/imo-commends-nimasa-navy-on-fight-against-piracy/. Accessed 25 July 2020

Global, D (2020) IMO commends NIMASA, navy on fight against piracy. https://www.dryadglobal.com/imocommends-nimasa-navy-on-fight-against-piracy/. Accessed 31 July 2020

Gosalbo-Bone R, Boelaert S (2015) The European Union's comprehensive approach to combating piracy at sea: legal aspects. In: Koutrakos P, Skordas A (eds) The law and practice of piracy at sea, European and International perspectives. Hart Publishing, Oxford

Harper, M (2014) Danger zone: chasing West Africa's pirates, BBC News, Nigeria, British Broadcasting Corporation [BBC]. https://www.bbc.co.uk/news/world-africa-30024009. Retrieved 4 August 2020

Hassan, T (2015) Proliferation of piracy on Nigerian waters and its economic effects. The Union. https://www. theunion.com.ng

Ibrahim J (2000) In: Jega A (ed) The transformation of ethno-regional identities in Nigeria, identity transformation and identity politics under structural adjustment in Nigeria. Nordiska Afrikainstitutet and Centre for Research and Documentation, Stockholm

Igbokwe, M (2015) Evaluating maritime piracy and security in Nigeria, national mirror. http://www. nationalmirroronline.net/new/evaluating-maritime-piracy-and-security-in-nigeria/

Ikelegbe A (2005) The economy of conflict in the oil rich Niger Delta region of Nigeria. Nord J Afr Stud 14 2:208-234

International Maritime Bureau [IBM] (2019) Gulf of Guinea World Piracy Hotspot. https://www.icc-ccs. org/index.php/1279-seas-off-west-africa-world-s-worst-for-pirate-attacks-imb-reports. Retrieved 27 July 2020

Jimoh, A (2015) Maritime piracy and lethal violence offshore in Nigeria. IFRA-Nigeria Working Papers Series, no. 51

Kania, R. R. E (2009) Piracy and Islamic Host States. Paper for the 5th Irish Criminology Conference. Dublin, Ireland

Kania R. R. E, Nwalozie C (2010) Socio-political correlates of modern piracy. Paper for the European Society of Criminology, Liege September 2010

Kelley RP (2011) UNCLOS, but no cigar: overcoming obstacles to the prosecution of maritime piracy. Minn Law Rev 95-6:2289-2317

Knorr, A (2015) Economic factors for piracy: the effect of commodity price shocks. http://piracy-studies. org/economic-factors-for-piracy-the-effect-of-commodity-price-shocks/\#more-1360. Retrieved 25 September 2015

Kontorovich, E (2009) International legal responses to piracy off the Coast of Somalia. Am Soc Int Law 13-2. http://www.asil.org/insights/volume/13/issue/2/international-legal-responses-piracy-coast-somalia. Retrieved 22 August 2015

Lhuillery, J (2008) Nigeria becomes world piracy hot spot. Mail \& Guardian Online. http://www.mg.co. za/article/2008-05-20-nigeria-becomes-world-piracy-hot-spot. Retrieved 6 May 2009

Marenin O, Reisig MD (1995) A general theory of crime and patterns of crime in Nigeria: an exploration of methodological assumptions. J Crim Just 23:501-518

Mberu BU (2005) Who moves and who stays? Rural out-migration in Nigerian. J Popul Res 22:141-161

Nigerian Navy (2007) History of the Nigerian Navy. Nigerian Navy official website. http://www. nigeriannavy.gov.ng/history.aspx. Retrieved 12 May 2009

Nightingale, L (2019) Piracy problem is a threat to Nigeria's maritime economy. https://loydslist. maritimeintelligence.informa.com/LL1129132/Piracy-problem-is-a-threat-to-Nigerias-maritimeeconomy. Retrieved 28 July 2020

Nincic, D. J (2009) Maritime piracy: implications for maritime energy security. J Ener Securi. http:// www.ensec.org/index.phpoption=com_content\&view=article\&id=180:maritime-piracy-implications-formaritime-energy security\&catid=92:issuecontent\&Itemid=341. Retrieved 12 May 2009

Nodland A, Odin H (2007) Security in the Niger Delta. Bergen Risk Solutions, Bergen 
Odunsi, W (2020) NDDC: judge, ex-Govs, APC Chiefs, Security officials allegedly got commission's contracts. https://www.dailypost.ng/2020/07/28/nddc-judge-ex-govs-apc-chiefs-security-agenciesallegedly-got-commissions-contracts/. Accessed 31 July 2020

Ogbonnaya, M (2020) Maritime: is Nigeria's new anti-piracy law enough to combat maritime piracy? https:/enactafrica.org/enact-observer/is-nigerias-new-anti-piracy-law-enough-to-combat-maritime-piracy. Retrieved 27 July 2020

Oladele, K (2007) Nigeria: Structural constraints to socio-economic development in Nigeria, (3) The Vanguard. https://www.allafrica.com/stories/200711020067.html. Accessed 19 Aug 2020

Okoronkwo U. L, Okpara E. N, Chieke E. O (2014) National security and maritime piracy in Nigeria: a sociological discourse. Humanit Soc Sci Lett 2(1):60-71

Oseghale, C (2015) Security agencies move against sea pirates, punch. http://www. punchngcom/business/maritime/security-agencies-move-against-sea-pirates/. Retrieved 1 October 2015

Oyefusi A (2006) Propensity to civil disobedience and the probability of an armed struggle in the Niger Delta region of Nigeria. University of Benin, Benin

Peel, M (2005) Africa programme: armed non-state actors project. Crisis in the Niger Delta: how failures of transparency and accountability are destroying the region. London. Chatham House

de Perouse Montclos M-A (2012) Maritime piracy in Nigeria: old wine in new bottles? Stud Confl Terrorism 35:531-541

Ponniah, K (2020) The day the pirates came. https://www.bbc.co.uk/news/world-asia-52295222. Retrieved 28 July 2020

Prins, B (2020) Global sea piracy ticks upward, and the coronavirus may make it worse. https:/theconversation.com/global-sea-piracy-ticks-upward-and-the-coronavirus-may-make-it-worse137586. Retrieved 27 July 2020

Ralby, I. M (2020) Nigerian Navy thwarts Hijacking of Chinese fishing vessel. https:/www.maritimeexecutive.com/article/nigerian-navy-successfully-interdicts-maritime-kidnapping-attempt. Retrieved 27 July 2020

Reuters (2013) IMF sees Nigeria economy picking up steam in 2013. Yahoo! News, 29 March 2013. http://news.yahoo.com/imf-sees-nigeria-economy-picking-steam-2013-082426820\%2D\%2Dbusiness. html. Retrieved 7 April 2013

Rider, D (2015) Is Nigeria's territorial water safe? Marit Secur Rev

Rotimi A (1984) Perspectives on the armed robbery offence. Indian J Criminol 12:122-135

Saharareporters (2020) Justice Dimgba, army GOC 6 division, police AIG operations, DIG, ex-governors, APC chieftains, EFCC official listed as beneficiaries in NDDC contract. http://saharareporters.com/2020 /07/28/justice-dimgba-army-goc-6-division-police-aig-operations-dig-ex-governors-apc-chieftains. Retrieved 31 July 2020

Sky News (2018) Pirates kidnap 12 crew from Swiss ship off Nigeria. https://news.sky.com/story/pirateskidnap-12-crew-from-swiss-ship-off-nigeria-11506071. Retrieved 2 December 2018

The World Bank, (2019) Nigeria: overview. https://www.worldbank.org/en/country/nigeria/overview\#1. Retrieved 30 July 2020

United Nations (2017) World population prospectus, key findings, 2017 revision

United Nations Office on Drugs and Crime [UNODC] (n.d.) Maritime piracy in the Gulf of Guinea. https:/www.unodc.org/documents/toc/Reports/TOCTAWestAfrica/West Africa TOC PIRACY.pdf. Retrieved 25 September 2015

Usman, E (2012) Top government officials, politicians contract us - Sea pirates. https://www.vanguardngr. com/2012/12/top-government-officials-politicians-contract-us-sea-pirates/. Retrieved 5 August 2020

Watts M (2008) Anatomy of oil insurgence: violence and militants in the Niger Delta, Nigeria. In: Omeje K (ed) Economies and conflicts in the global south: multi-regional perspectives on Rentier politics. U.K. Ashgate Publishing Company, Aldershot

Publisher's note Springer Nature remains neutral with regard to jurisdictional claims in published maps and institutional affiliations. 